\title{
EXPERT TESTIMONY, ITS ABUSE AND REFORMATION.
}

\author{
"Believe no expert" says the cynic Bar, \\ Yet how unjust-all alike deride. \\ This swears white black; but straightway-haud impar- \\ An equal sage approves the candid side.
}

Mr. Justice Darling "On the Oxford Circuit."

Almost from the beginning of the use of expert testimony in our courts a conflict has been waged over its real probative value in settling vexed and close questions of fact. The position of an expert on the witness stand, who does not testify either to what he has observed or knows as fact but expresses merely his opinion as to a situation or on facts which have been established by other witnesses, is anomalous in Anglo-Saxon law. It was to be expected that former generations of judges and lawyers trained in older precedents and practices who recognized the appearance in the courts of an expert witness as an innovation would look with suspicion and doubt on such testimony. While the principles on which such evidence is introduced have come to be well recognized and while the profession no longer has any reservation in approving theroretically of the use of expert testimony, yet, on the other hand, there is a constant complaining and mistrust on the part of judges, juries and lawyers of the expert witness. It is by no means common to see juries show their contempt for the expert testimony which has been only too elaborately and lavishly introduced before them by throwing completely aside and absolutely disregarding all such evidence from the case. They do not attempt to weigh the honors, learning, experience or standing in the profession of one expert who is contradicted by another socalled expert who qualifies by an equally long, if less substantial, list of distinctions. They do not attempt to compare the relative value or reasonableness of conflicting expert testimony. Unless' one of the experts makes an absolute fool of himself, one opinion carries about as much, or perhaps better, as little weight as another. To the jury an expert is an expert-a kind of intellectual prostitute ready to sell his opinion and enlist in the services of the side that pays him. With juries, at least, experience with this testimony has demonstrated that "an ounce of fact is worth a pound of opinion." 
If a jury appears to be more than ordinarily respectful in its attitude towards the expert witnesses, then the trial judge is only too apt to step into the breach with a timely warning. Instructions to juries vary in degree from merely calling to their attention the fact that the experts are called by the contestants, to such extreme expressions of personal opinion as: "I have been long of the opinion that evidence of this description which in strictness of law is receivable ought, if received, to have no great weight given it, but of course it is for you to say just how much, etc., etc." Frequently judges have characterized it as "testimony of a dangerous character not much to be relied on," or "of the very lowest order that is ever allowed in a court of justice."

Then if by any chance expert testimony seems to have played any real part in the determination of issues at misi prius, the courts of appeal take their turn to discredit the expert witness. Naturally their comments cover a wide range and many aspects of this question in the course of numberless decisions in our many courts of appeal take their turn in discrediting the expert witness. of them come down to the same thing. And this has, perhaps, been best expressed by Mr. Justice Curtiss: "I believe the experience of all concerned in the administration of justice tends to the conclusion that this species of evidence is less satisfactory than any other; and it is common remark that when there is any room for a difference of opinion, experts in about equal numbers, will generally be found testifying on each side." 1

The result of all this is that a class of testimony that is not only legally admissible but logically of large probative value to a correct solution of intricate questions of fact has lost most of its effectiveness. The faults and abuses are those of practice. Now that this is so universally recognized the profession is beginning to bestir itself on the subject and to suggest and to plan reforms.

The faults to be remedied are obvious and more or less clearly defined. At a recent meeting of the New York State Bar Association a committee appointed to consider this subject classified the existing evils in the use of medical expert testimony under six heads:

1 Wilkinson v. Greely, I Curtis (U. S.), 439 Fed. Cas., 17,672. To almost the same effect is Mr. Justice Miller in Middling Purifier Co. v. Christian, 4 Dill., 448, 459: "My own experience, both in the local courts and in the Supreme Court of the United States, is that whenever the matter in contest involves an immense sum in value, and when the question turns mainly upon opinions of experts there is no difficulty in introducing any amount of them on either side." 
"First-Want of satisfactory standards of expertness with its result of inviting the testimony of charlatans.

"Second-The partisan conflicting and hence unreliable character of the evidence often given by so-called expert witnesses.

"Third-The prolongation of trials and the consequent increase of expense on account of the number of witnesses.

"Fourth-The confusing effect on juries of the contradictory testimony of expert witnesses of apparently equal standing, having the same opportunity for acquiring knowledge of the facts which their conflicting opinions are predicated.

"Fifth-The lack of scruple upon the part of some members of the Bar in countenancing the hiring by their clients of unprincipled self-styled experts to support causes by specious and untruthful testimony.

"Sixth-An unfortunate tendency upon the part of some trial judges to permit incompetent so-called medical experts to testify to opinions predicated upon widely unrelated facts and under oath to express views which are but the speculative vagaries of illinformed minds." 2

While perhaps everybody will not subscribe to these particular six specifications of evils, almost all can agree that the primary cause of all the trouble is in the personnel of the witnesses who are allowed to testify as experts. Experience has demonstrated that the witnesses who give expert testimony are not in fact qualified to testify as such, and secondly, that they are not honest in their testimony.

Already two States have tried to remedy the situation by statute. Michigan ${ }^{3}$ has passed a statute limiting, in cases other than prosecutions for homicide, the number of expert witnesses who may be called by a side to three, except where the court expressly permits more. It limits compensation to ordinary witness fees and makes it a criminal offense to pay or to receive more, unless the court before whom such a witness appears awards him a larger sum. In case of homicide, the court appoints "one or more disinterested persons" to testify as experts and be paid by the county such sum therefor as the court fixes. The Rhode Island statute ${ }^{4}$ provides for the appointment, on motion of

2 Report of the Committee on the Regulation of the Introduction of Medical Expert Testimony. Thirty-second Annual Report, New York State Bar Association.

3 Mich. Public Acts, 1905, No. I75.

4R. I. Court and Practice Act, I905, § 370-373. 
any party, of an expert whose fees may be taxed as costs against the losing party who shall make a report to the court and be thereafter examined at the trial. Other experts may be called by either party. Neither of these statutes limits the parties to the official experts.

Practically both of them will probably prove ineffective. The Rhode Island statute leaves the real evil untouched, while in practice the Michigan statute will in all likelihood degenerate into a custom of three experts to a side whose fees will ordinarily be approved as a matter of course upon ex parte applications.

Various other remedies have been under consideration by the legislatures of other States. Thus in Massachusetts one proposition was to give the trial judges authority to charge juries on the facts concerning matters covered by expert testimony and on the testimony itself. But the judges in the United States courts already have this power and the evil is as great there notwithstanding the influence of the presiding justice.

In Massachusetts, Maine and New York another remedy suggested has been the creation of a body of court experts one of whom is to be designated by the judge for each case whose report or testimony shall be given consideration above that of experts called by the parties. In Maine and New York the fees were to be paid the expert by the State, while in Massachusetts after such payment the State was to be reimbursed by the defeated party. The proposed Massachusetts Act was the work of a joint committee of the Massachusetts Medical Society and the Boston Bar Association, and although the most elaborate and carefully prepared of this class of legislation it failed to pass the Massachusetts Legislature of 1908 to which it was presented ${ }^{5}$ and has not again been agitated.

5 " $\$$ I. At any time during the pendency of any action, suit or proceedings, civil or criminal, the court or any justice thereof in chambers, or in vacation, in any county, on his own motion may, and at the request of either party shall, appoint one or more persons, learned in the science of medicine, of not less than five years' actual practice thereof, and recommended as hereinafter provided by the leading incorporated medical society of the Commonwealth as official medical or surgical expert advisers who shall investigate the facts of the case and give their expert opinion on any material professional question arising therein and make written report thereon to the court.

"§ 2. Such reportishall be opened and filed in the case and shall have the same effect (and thè parties shall have the same rights with reference 
None of these draft acts propose to do away with experts called by litigants. Nor do any of them give very real assurances that the official medical experts will be any better qualified or any more honest than now. The only improvement promised is that at least one expert in the case will be disinterested. As long as parties have a right to have issues tried by a jury, there is in such trial no "official" place for the expert. He can have no functions except that of witness. On the other hand a very interesting question is raised as to the effect and status in our courts of such an official expert witness. If he is to be crossexamined and contradicted by other unofficial experts in open court, and it is to be left to the jury to judge of the weight of

thereto) as now given to the report of an auditor appointed by the court. Such expert upon the trial of the case may be called as a witness by either party.

"§ 3. The Massachusetts Medical Society, the Massachusetts Homeopathic Medical Society and the Massachusetts Eclectic Medical Society shall each through their respective governing bodies, annually before the first day of October, furnish to the Chief Justice of the Superior Court a list of not less than fifty names of physicians of good professional standing in the various counties of the Commonwealth and not less than five years' actual practice in their profession, whom they recommend as competent to serve as such expert witnesses, designating the specialty in which they are deemed to be experts, and giving their addresses, which lists shall be posted in the clerk's offices of the several courts.

"§ 4. Upon such appointment by the court, or if the parties file an agreement designating an expert for the case, the clerk shall issue an order to the person so appointed or agreed upon, to be served in the manner provided by law for the service of subpoenas. As soon as may be after service thereof, the expert witness shall make such examination of the case as in his judgment may be necessary and practicable, and shall file his report thereon as above provided.

"§5. Such witness shall be paid for his services a reasonable compensation, to be allowed by the court and paid out of the treasury of the county. In all civil actions and proceedings the defeated party shall be liable to refund the amount so disbursed, including the service of the order, and after final judgment in the cause, execution may issue against him therefor in favor of the county commissioners, or in the county of Suffolk of the city of Boston.

"§6. Either party may call other medical witnesses than those designated by the court, but at his own expense, and only the ordinary witness fee allowed by law shall be taxed against the defeated party for such additional witnesses.

" $\$ 7$. The refusal of any person to be examined by a physician appointed as herein provided shall be admissible in evidence.

"§8. This act shall take effect upon its passage." 
this testimony by what it hears and sees, there will be very little gained in the long run. If on the other hand, he is not to be so cross-examined or contradicted, then you are introducing a fundamental change in our trial system which will not commend itself generally either to the profession or the laity. This is no new aspect of the problem. More than twenty-five years ago Sir Fitzjames Stephen" expressed his opinion on this subject: "This is the question:-Which is right, the present system according to which skilled witnesses are called by each side at the discretion of the parties and are examined and cross-examined like other witnesses, or a proposed system according to which such witnesses should be appointed by the court and occupy a position more or less resembling that of assessors? The matter has been often discussed, especially by medical men. I have the strongest possible opinion in favor of the maintenance of the present system for the following reasons: Our present system provides a definite place and definite rights and duties for the parties, the judge, the jury, and the witnesses. What room there is for any other persons in the proceedings I do not see. It is impossible to say what an expert is to be if he is not to be a witness like other witnesses. If he is to decide upon medical or other scientific questions connected with the case so as to bind either the judge or the jury, the inevitable result is a divided responsibility which would destroy the whole value of the trial. If the expert is to tell the jury what is the law-say about madness-he supersedes the judge. If he is to decide whether, in fact, the prisoner is mad, he supersedes the jury. If he is only to advise the court, is he or is he not to do so publicly and to be liable to cross-examination? If yes, he is a witness like any other. If no, he will be placed in a position opposed to all principle. The judge and the jury alike are and ought to be, instructed only by witnesses publicly testifying in open court under oath. It never would be, and never ought to be, endured for a moment that a judge should have irresponsible advisers protected against cross-examination."

This incisive analysis of the situation is as pointed and true today as it was when first written and disposes of many of the recent proposed reforms. The remedy is not in the enactment of any new statute. No act of the legislature will make witnesses learned or honest. The reform must come from the professions themselves-from the practicising lawyers, from the physicians

${ }^{6}$ I Stephen: History of Criminal Law of England, pp. 574-5. 
and other classes of expert witnesses. As long as it is profitable to use or to give fake expert testimony, and as long as it can be bought and sold without loss of professional standing, so long will it appear in the trial courts. Only the other day the inquiry directed to establish Thaw's sanity again served to draw public attention to this subject in a marked manner. According to the newspaper account Dr. $X$, after testifying that Thaw had no incurable mental disease was confronted with the notes of a report he made to Thaw's counsel before the first trial. In this document he burdened Thaw with a hereditary malady with a sequence of aberrations that amounted to a chronic ailment. The reporter naively adds that $\mathrm{Dr} . \mathrm{X}$ did not have much success, explaining that this volume of opinions was merely a "medical brief" for the use of Thaw's counsel in the trial.

Today in any large city if an attorney calls to retain a physician in a personal injury case, the first question which the physician will probably ask is by which "side" of the case he is retained. If the physician is one who is constantly appearing in court, he will refuse to accept a retainer from a plaintiff if his appearance has been generally on the defendant's behalf, and vice versa. From his point of view to mix "sides" is bad business. So the regular court experts not only come to be tagged in court as "plaintiff's experts" or "defendant's experts," but they come in their practice more or less unconsciously to get into a chronic one-sided medical point of view. Habitually, the plaintiff's expert sees or magnifies injuries, symptoms and resultant ill effects which the defendant's experts minimize or "pooh pooh" altogether. The plaintiff's expert has argued and reasoned himself into a frame of mind that sees in the given case just what the plaintiff's attorney needs. On the other hand, the defendant's expert sees a malingerer in every man who asks damages. It is the old story of bringing to the market what the market demands. If deformities are the fashion, deformities are cultivated. We are not talking of charlatans. The doctors who are doing this are the leaders in their profession who qualify with respectable medical degrees, professorships in leading medical colleges, and membership in the principal medical societies. Now as long as these men can do this and remain leaders in their profession, just so long is any chance at real reform postponed. Just as long as a leading physician can accept a general retainer from a street railway company and appear day after day in case after case as a "de- 
fendant's expert" and retain his professional respectability, just so long will you have "plaintiff's experts" and "defendant's experts." When the medical profession sets a moral standard that demands that a physician, testifying under oath in court, must state his opinion fairly and fully without bias and without regard to the side that calls him, neither suppressing nor over-emphasizing any aspect of the case, then, and only then, you will have real medical expert testimony. When once you have that standard established the charlatans and fake experts will be driven from the courts, because what they have to offer cannot be successfully used.

There can be no question but that the attorneys are no less blameworthy than the experts they use. An attorney who would refuse to present fake testimony to the court in ordinary matter does not hesitate to employ biased or fake expert witnesses. It is the practice and demands of lawyers which have created the "plaintiff's expert" and "defendant's expert." If they did not buy, the doctors would not sell. The average accident lawyer wants the doctors properly labeled. It is a handy short cut and prevents mistakes. It would be embarrassing to call in an expert and find that he was of the opinion that the plaintiff really was suffering the injuries claimed when you are trying a run for luck with the jury in the hope that you may come out better than the offer of settlement. On the other hand, it might be equally fatal to engage an expert to examine your client without knowing in advance that he will be able to help substantiate the claim.

If one expert does not give the lawyer what he demands, he does not hesitate to discard him and search the market until he finds what he wants. If he cannot get the real article, he furbishes up the counterfeit and passes it off on the jury. If he finds that the genuine expert opinion is against him, he may at least deliberately play the game with the counterfeit to disgust the jury with all expert testimony and even up things by leading the jury to disregard it for both sides. There is a doctor in Boston who is notorious about the courts as a plaintiff's expert. $\mathrm{He}$ is ingenious and experienced, and when hard pushed an attorney may always go to him and be sure to find what he seeks. Judges and lawyers all know what his appearance in a case signifies, yet he appears in court almost as constantly as any of the regularly retained corporation "defendant's experts." The lawyers who 
use him and share the spoils of victory with him on a contingent basis retain their standing at the bar.

Ambulance chasing has ceased to be respectable for an attorney because the profession frowned upon it, and no attorney today would, openly at least, resort to it. The present standards of professional conduct have advanced to that degree that the barter and sale of testimony from any witness except an expert, is outside the range of almost all court experience. A lawyer who would absolutely refuse to pass a counterfeit bill will unhesitatingly palm off counterfeit expert testimony on a jury. As long as there are law suits there will always be some lawyers who will look upon them as games to be played and won by any means that the rules allow. Therefore as long as the standards of the profession countenance this abuse, so long will it continue. Whenever the good lawyers will not, the shysters cannot, continue to misuse expert testimony. The standard and methods of the best lawyers in practice set the fashion in the court room which all who would succeed must follow as surely as the fashions are set by leaders and followed in the world at large.

The repudiation of this class of testimony so generally by juries has made it so ineffective that the question of its use is now a live and practical issue that has to be considered in the preparation for trial of any case when its use is a possibility. In many a case expert testimony is deliberately omitted where but for its abuses it would have a legitimate and useful place. If the use of expert testimony is to continue, it must regain the confidence and respect of courts and juries. This it can only do when it becomes the general practice for the lawyers who introduce such evidence to sift out the real from the false, test it in the first instance by their own judgment, experience and proper professional standards, and reject whatever does not measure up to such standards.

Good must come from the general agitation of this question. The profession has recently shown what interest it can arouse throughout the country by agitating questions of professional ethics. As the general professional demand eventually crystalized itself into the Code of Professional Ethics, so slowly and surely the good sense of the profession can, and must, set up standards in the use of expert witnesses which will make them effective and useful instruments of justice and restore this class of evidence to its natural place in the trial of cases. 
It is no answer to these suggestions to say that they are well enough as far as they go but they do not present anything suffciently tangible. The establishment of a proper professional standard is the first step. Then if the professions once establish standards that mark the distinction between honorable and dishonorable professional conduct, then where public sentiment alone fails to enforce obedience to its dictates the courts always have it in their hands to coerce observance thereto by harsher and more compelling means. Only recently we have seen how strikingly and effectively a Federal court in New York dealt with the case of an attorney who advised and in a measure assisted his client to evade the production of his books in answer to a subpoena. In doing as he did, the attorney violated no statute. In advising his client to commit a contempt of court his only sin was against the canons of professional decency. While a fine was imposed it was rather the censure which the judge admininstrated to the attorney that compelled both him and his client to undo the wrong. In the country at large, however, the firm stand of the court drew the attention of the profession to the fact that such practices were dishonorable and that no self-respecting lawyer will indulge in such, and that no self-respecting court will submit to them. For the future this problem is settled.

Again, where ambulance chasing is frowned upon, strong action on the part of the court settles that difficulty with equal ease. In the Supreme Court of New York an attorney was lately suspended from practice for a year for that offense. The court said:

"It (ambulance chasing) is a practice that has been commented upon and criticised at meetings of lawyers and in judicial decisions as well as by the general public, and now, when it is for the first time in this department brought directly before the court, it is our duty to speak in no uncertain terms in condemning it as a violation of the criminal law in this State and also a practice which is unprofessional and destructive of the honor of the profession and of the confidence of the community in the integrity and honor of its members.

"It has been urged in extenuation of this offense that it is a practice which is common among members of the profession who are engaged in the prosecution of negligence cases, and that it is unfair to visit upon the offender, who has first been brought before the court upon a charge of this character, the extreme punishment of disbarment, and a majority of the court are of the opinion that this fact should be considered, and that instead of 
disbarment the respondent be suspended from practice for one year.

"We wish it to be distinctly understood, however, that after this expression of the views of the court upon the nature of the offense, the considerations that have influenced a majority of the court in deciding upon this punishment, rather than disbarment, will not be considered upon further conviction of practice of this kind." 7

If once it becomes plain to lawyers, judges and witnesses that the abuse of expert testimony is unprofessional, then just as courts have protected themselves against dishonest advice or dishonorable soliciting of employment on the part of attorneys, so they may be equally armed to protect themselves from the misuse of experts when the lack of good taste on the part of the practitioner needs admonition stronger than the "Don' $t$ " of the profession.

Boston, Mass.

Lee M. Friedman.

In re Shay, II8 New York State, I52. 